\title{
LESSONS ON PARENTAL LEAVE: A COMPARATIVE ANALYSIS OF PARENTAL LEAVE IN SOUTH AFRICA AND THE UNITED KINGDOM
}

\author{
Asheelia Behari \\ LLB LLM PhD \\ Postdoctoral Research Fellow \\ University of KwaZulu-Natal
}

\begin{abstract}
SUMMARY
Recent amendments to the Basic Conditions of Employment Act 75 of 1997 have resulted in the introduction of parental leave. This provides employees with 10 consecutive days of time off from work to care for their newborn babies and may commence from the day of the birth. The right to parental leave has the additional benefit of impacting gendered social assumptions that place women in the primary role of caregiver and a secondary role as worker. With the rise in the labour participation of women, there has been an increase in the need for the involvement of men in the caregiving and upbringing of children in the home. Although parental leave applies to men and women, it has been enacted with the objective of encouraging working fathers to participate as caregivers and to share in the burden of care placed on new mothers to care for themselves and their newborn babies during maternity leave. This article considers the effects of parental leave as a recent addition to South African law by conducting a comparative analysis with the longestablished parental leave models of the United Kingdom. These include the right to parental leave that is applicable to a parent who has parental responsibility for a child, and a right to shared parental leave, which allows the mother of the child to share her maternity leave with the other parent of the child. The parental leave rights of the United Kingdom have been developed to provide employees with choice and flexibility to accommodate their caregiving responsibilities, and may indicate a trajectory for the progression of the newly enacted right to parental leave in South Africa.
\end{abstract}

\section{$1 \quad$ INTRODUCTION}

The Labour Laws Amendment Act (LLAA) ${ }^{1}$ introduces the rights to parental leave, adoption leave and commissioning parental leave to the Basic Conditions of Employment Act (BCEA). ${ }^{2}$ The amendments follow criticisms that have trended in academic literature and elsewhere and which recommend the introduction of leave entitlements inclusive of fathers in

\footnotetext{
10 of 2018.

275 of 1997.
} 
South African labour legislation. ${ }^{3}$ In response, the amendments were proposed with the primary objective of recognising the role of fathers in the upbringing of their children, and of encouraging the bond between fathers and their children. ${ }^{4}$ Comparative research has indicated that several countries have amended their labour legislation to provide for parental leave on the basis that leave that is inclusive of fathers is recognised as the first step towards the reconciliation of work and caregiving. ${ }^{5}$ Different countries have adopted different models of parental leave that vary as to eligibility requirements, duration of leave, the attachment of a minimum age for the child to be cared for, cash benefits, and the flexibility and transferability of the leave between parents. ${ }^{6}$

However, the primary purpose of parental leave that is offered to both mothers and fathers is to allow both parents time off from work to care for their child - from the stages of infancy to young childhood. ${ }^{7}$ While the right to parental leave is couched in gender-neutral terms, it may nevertheless fail effectively to support both working mothers and fathers with their care responsibilities.

This article considers the provision for parental leave in the model accepted into the BCEA. The parental leave laws of the United Kingdom (UK) have been selected for comparative analysis as the UK model has evolved through family-friendly reforms initiated by the UK government since 1997. ${ }^{8}$ The UK provisions of various leave options and a widened scope of entitlements to time off from work for the purposes of caregiving gives employees the flexibility and choice to cater to their care-giving responsibilities. The comparative analysis in this article is aimed at examining the existing parental leave model of the UK so as to identify areas for development in the newly enacted South African parental leave model.

\section{THE RELATIONSHIP BETWEEN MATERNITY LEAVE AND PARENTAL LEAVE}

Social values place greater emphasis on the paid work of employees than on the unpaid work of family carers. ${ }^{9}$ This affects women who attempt to

3 Dancaster "State Measures Towards Work-Care Integration in South Africa" in Mokomane Work-Family Interface in Sub-Saharan Africa: Challenges and Responses (2014) 186.

4 GN 1174 in GG 39445 of 2015-11-25, Memorandum on the Objective of the Labour Laws Amendment Bill, 2017, clause 1.1.

5 Dancaster and Baird "Workers With Care Responsibilities: Is Work-Family Integration Adequately Addressed in South African Labour Law?" 200829 ILJ 22 35; Field, Bagraim and Rycroft "Parental Leave Rights: Have Fathers Been Forgotten and Does It Matter?" $201236(2)$ SALR 30.

6 ILO "Maternity and Paternity at Work: Law and Practice Across the World" http://www.ilo.org/maternityprotection (accessed 2020-01-07) 61.

7 ILO http://www.ilo.org/maternityprotection 60.

8 Conaghan "Work, Family and the Discipline of Labour Law" in Conaghan and Rittich (eds) Labour Law, Work and Family (2007) 19 27; James The Legal Regulation of Pregnancy and Parenting in the Labour Market (2009) 39.

9 Dancaster and Cohen "Family Responsibility Discrimination Litigation: A Non-Starter?" 2009 2 Stell LR 221 228; Cohen "The Efficacy of International Standards in Countering Gender Inequalities in the Workplace" 201233 ILJ 1924. 
balance their responsibilities as paid employees with those as unpaid caregivers and homemakers. ${ }^{10}$ Gendered assumptions have led to "systemic barriers" that have carried through to the workplace. Such barriers obstruct the rights of women to attain full-time employment by placing the care-giving role of women in opposition to the role of the "ideal worker". 11 The ideal worker is perceived as a person who functions in the primary role of full-time employee and who has little or no role as a family carer for the purposes of childbearing or childrearing. The ideal worker is assumed to be male (a gendered assumption) and workers with care-giving responsibilities are excluded from performing as ideal workers. ${ }^{12}$ Social ideals reflect further that an employer is more likely to consider a man, rather than a woman, to be the type of employee who can work long hours without interruption. ${ }^{13}$ Thus, most women are in reality excluded from fulfilling the role of the ideal worker. ${ }^{14}$

Although women are not considered as "ideal workers", the labour participation of women has been increasing steadily over several years. ${ }^{15}$ For instance, the labour force participation of women has increased from 38 per cent in 1995 to 53,3 per cent in $2018 .{ }^{16}$ The increased labour participation of women has added to the conflict between work and care in South Africa. ${ }^{17}$ South Africa has a large percentage of households headed by women. This is particularly true in rural areas, where women live apart from their husbands and care for the children. ${ }^{18}$ These households are often vulnerable and lack financial resources. This means that more women from rural homes must seek income-producing employment. ${ }^{19}$ Therefore, women often fulfil dual roles as both worker and carer.

However, owing to their care-giving responsibilities, women are more likely to be found in atypical employment that allows them to work on a parttime basis. Part-time employment provides an employee who has care-

10 Cohen 2012 ILJ 30.

11 Cohen 2012 ILJ 30; and Clarke and Goldblatt "Gender and Family Law" in Bonthuys and Albertyn (eds) Gender, Law and Justice (2007) 195203.

12 Cohen 2012 lLJ 30.

13 lbid.

14 Adams "The Family Responsibilities Convention Reconsidered: The Work-Family Intersection in International Law Thirty Years On" 2013-2014 22 Cardozo J, Int'l and Comp L 201 211; Bonthuys "Gender and Work" in Bonthuys and Albertyn (eds) Gender, Law and Justice (2007) 245249 250; Dupper "Maternity Protection in South Africa: An International and Comparative Analysis (Part One)" 20013 Stell LR 421.

15 Adams 2013-2014 Cardozo J, Int'l and Comp L 208; Huysamen "Women and Maternity: Is There Truly Equality in the Workplace Between Men and Women, and Between Women Themselves?" in Malherbe and Sloth-Nielsen (eds) Labour Law Into the Future: Essays in Honour of D'Arcy du Toit (2012) 46; Smit "The Changing Role of the Husband/Father in the Dual-Earner Family in South Africa" 2002 33(3) Journal of Comparative Family Studies 401 402.

16 Quarterly Labour Force Survey - P0211: 4th Quarter 2018 Appendix 1, Table 2 (Quarterly Labour Force Survey 2018) (2 February 2019) http://www.statssa.gov.za (accessed 202001-05).

17 Cohen and Gosai "Making a Case for Work-Life Balance for the South African Employee" 201637 ILJ 2237

18 Clarke and Goldblatt in Bonthuys and Albertyn Gender, Law and Justice 198; Bonthuys in Bonthuys and Albertyn Gender, Law and Justice 247.

19 Clarke and Goldblatt in Bonthuys and Albertyn Gender, Law and Justice 197198. 
giving responsibilities with the dual benefits of income and flexibility. ${ }^{20}$ When women cannot reconcile their work and care-giving responsibilities, they tend to resort to voluntary withdrawal from employment by resigning for the purpose of attending to their care-giving responsibilities. ${ }^{21}$ To address these issues and in the interest of affording equal opportunities to men and women in the workplace, maternity leave was first legislated in South Africa via provisions in the now-repealed Basic Conditions of Employment Act 3 of 1983.22 The objectives of providing for maternity leave are the protection of the health of the woman and child after birth and the provision of a necessary bonding period between mother and child. ${ }^{23}$

Section 25 of the current BCEA provides that a pregnant employee is entitled to four consecutive months' unpaid maternity leave. The leave can commence at any time from four weeks before the expected date of delivery or from a date certified by a medical practitioner or midwife. ${ }^{24}$ The employee is prohibited from working for six weeks after the birth of the child unless a medical practitioner or midwife certifies that it is safe for her to do so. ${ }^{25}$ This provision applies irrespective of whether or not the child is born alive. ${ }^{26}$ Thus, the BCEA sets out a compulsory leave period of six weeks. Maternity benefits are available through the Unemployment Insurance Act (UIA), to contributing employees, for a maximum period of 17.32 weeks of the maternity leave period. ${ }^{27}$

However, providing maternity leave without a corresponding period of paternity leave or parental leave creates an imbalance in family dynamics, as well as in the workplace. ${ }^{28}$ According to the International Labour Organisation's Resolution on Gender Equality at the Heart of Decent Work, there is an increase in women's labour force participation where legislative measures or policies offer parental leave. ${ }^{29} \mathrm{~A}$ legislative leave package that includes parental leave has been found to encourage shared parental

20 Ibid.

21 Dupper, Olivier and Govindjee "Extending Coverage of the Unemployment InsuranceSystem in South Africa" 201021 Stell LR 438 447; Huysamen in Malherbe and SlothNielsen Labour Law Into the Future: Essays in Honour of D'Arcy du Toit 65; Masondo $v$ Crossway (1998) 19 ILJ 180 (LC) 181C.

$22 \mathrm{~S} 17(b)$ of the Basic Conditions of Employment Act 3 of 1983 prohibited employees from working one month before and two months after confinement. Grogan Workplace Law (2014) 65; Kagnas and Murray "Law and Women's Rights in South Africa: An Overview" 1994 Acta Juridica 129.

23 Haas "Parental Leave and Gender Equality: Lessons from the European Union" 2003 20(1) Review of Policy Research 91.

$24 \mathrm{~S} 25(2)(a)$ and $(b)$ of the BCEA.

$25 \mathrm{~S} 25(3)$ of 75 of 1995.

26 S 25(4) of 75 of 1995 provides: "An employee who has a miscarriage during the third trimester of pregnancy or bears a stillborn child is entitled to maternity leave for six weeks after the miscarriage or stillbirth, whether or not the employee had commenced maternity leave at the time of the miscarriage or stillbirth."

27 S 24 of 63 of 2001.

28 Dancaster and Baird 2008 ILJ 22, 35; Behari "Daddy's Home: The Promotion of Paternity Leave and Family Responsibilities in the South African Workplace" 2016 37(2) Obiter 346 360 .

29 International Labour Conference (98th Session) Resolution concerning gender equality at the heart of decent work (Geneva, 19 June 2009) (Resolution on Gender Equality at the Heart of Decent Work) 6. 
responsibilities between parents, promote gender equality in the workplace and give recognition to the role of men in family participation. ${ }^{30}$ It provides these benefits by encouraging fathers to take time off work to care for their children, and thus to share with women in the burden of care while both the father's and mother's access to employment is maintained. ${ }^{31}$

In order to deliver these benefits effectively, fathers must be encouraged to take parental leave. ${ }^{32}$ Parental leave cannot change gender dynamics in the workplace and in households if only women employees are enjoying it. The use of parental leave by men may also prevent women from being pressured into resigning or from temporarily leaving employment for the sole purpose of taking care of young children. ${ }^{33}$ Take-up rates of parental leave by fathers are higher where it is offered as a non-transferrable, individual leave entitlement available to both fathers and mothers rather than as a single entitlement of parental leave that may be taken by either the mother or the father of the family. ${ }^{34}$ This encourages men to take the leave that is due to them by virtue of their roles as fathers. Fathers are also more likely to take parental leave if the leave is supplemented with income replacement and if they are provided with employment protection such as prohibitions against dismissal and discrimination on the basis of taking parental leave. ${ }^{35}$ Thus, in order to give effect to parental leave in a gender-neutral way, it must not only provide women with additional time to care for their babies after their maternity leave ends, but it must also provide supportive incentives for men to rely on parental leave.

\section{SOUTH AFRICA'S PARENTAL LEAVE MODEL}

With the introduction of parental leave, adoption leave and commissioning parental leave, the LLAA retains the right to maternity leave and deletes the entitlement to family responsibility leave for the birth of a child. The addition of parental leave is regarded as essential considering the inadequacy of the three days of family responsibility leave previously provided for in the BCEA, which was the only leave entitlement upon which fathers could previously rely in relation to the birth of a newborn baby. ${ }^{36}$

Accordingly, section 25A of the BCEA, as amended, provides that the parent of a child is entitled to at least 10 consecutive days of parental leave. There are no eligibility requirements for the entitlement to parental leave apart from that the employee should be the "parent" of the child. An employee may commence parental leave on the day that the child is born or

30 Behari 2016 Obiter 348; Smit "Family-Related Policies in Southern African Countries: Are Working Parents Reaping Any Benefits?" 2011 42(1) Journal of Comparative Family Studies 18.

31 ILO http://www.ilo.org/maternityprotection 61.

32 Ibid.

33 ILO http://www.ilo.org/maternityprotection 62; Dancaster in Mokomane Work-Family Interface in Sub-Saharan Africa: Challenges and Responses 188.

34 ILO http://www.ilo.org/maternityprotection 62.

35 Rycroft and Duffy "Parental Rights: Progress But Some Puzzles" 201940 ILJ 1225.

36 Behari "The Effect of the Labour Laws Amendment Bill 2017 on Shared Parental Responsibilities" 201839 ILJ 2148. 
on the day that the adoption order is granted. ${ }^{37}$ The employee must give the employer written notice of the intention to take parental leave at least one month before the date of the birth of the child, or of the day the adoption order is granted. ${ }^{38}$ The notice must be given in writing and must set out the date that the leave will commence and the date that the employee will return to work after the leave period. ${ }^{39}$

As with the right to maternity leave, the right to parental leave in the BCEA is unpaid and the employee has to rely on the Unemployment Insurance Act $(\mathrm{UIA})^{40}$ to claim parental leave benefits. ${ }^{41}$ Parental benefits are set out as an added amendment in section 26A of the UIA. This section states that the parental benefits are available to a contributing employee who: is either registered as the father of the child in terms of the Births and Deaths Registration Act; ${ }^{42}$ is the prospective adoptive parent of a child below the age of two; or is the parent of a child who has been born as a result of a surrogate motherhood agreement referred to in the Children's Act. ${ }^{43}$

Parental benefits may only be claimed if the employee meets the qualifying period attached to the entitlement. Section $26 \mathrm{~A}(5)$ of the UIA, as amended, states that the employee must have been in employment for at least 13 weeks before the date of the application for parental benefits. This is the same minimum period of employment that is applicable for the claim of maternity benefits. ${ }^{44}$ Furthermore, the right to parental benefits is only available to an employee who has not claimed adoption benefits or commissioning parental benefits. ${ }^{45}$ The parental benefit is paid at a maximum rate of 66 per cent of the earnings of the employee at the date of application. ${ }^{46}$ The benefits may not exceed the remuneration that the employee would have received if the employee had not been on parental leave. 47

\section{PARENTAL-LEAVE MODELS IN THE UNITED KINGDOM}

The regulation of work and care within labour law in the UK has largely been driven by political agendas. ${ }^{48}$ Introduced by the British New Labour

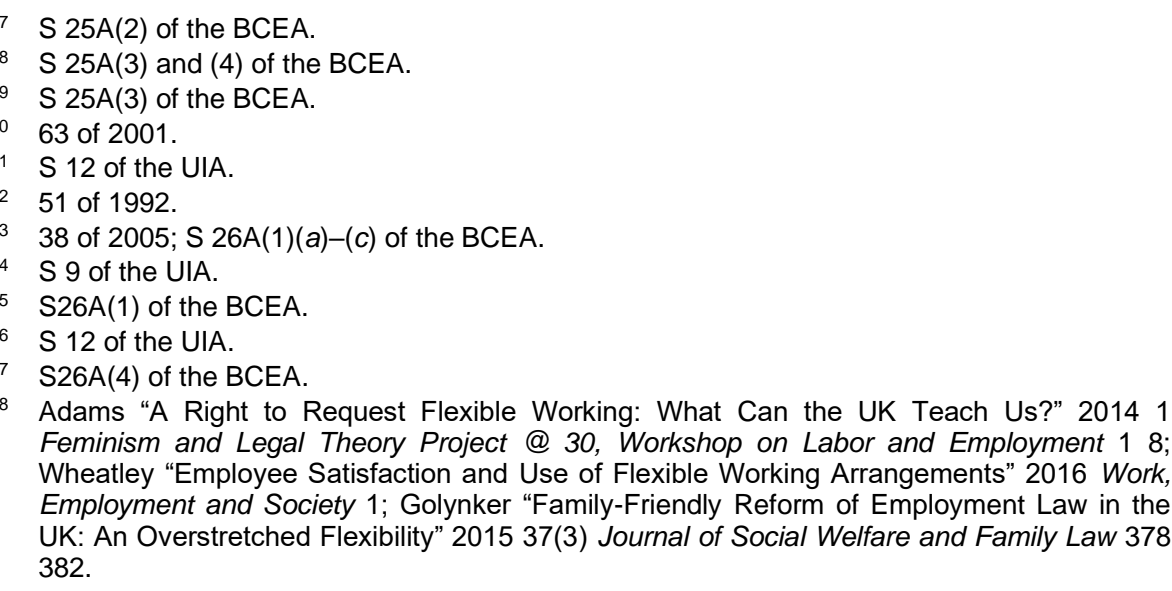

Adams "A Right to Request Flexible Working: What Can the UK Teach Us?" 20141 Feminism and Legal Theory Project@ @ 30, Workshop on Labor and Employment 18 Wheatley "Employee Satisfaction and Use of Flexible Working Arrangements" 2016 Work, Employment and Society 1; Golynker "Family-Friendly Reform of Employment Law in the UK: An Overstretched Flexibility" 2015 37(3) Journal of Social Welfare and Family Law 378 382. 
Government in 1997, family-friendly strategies have resulted in numerous policy initiatives and legal reforms aimed at the reconciliation of work and family responsibilities. ${ }^{49}$ Many of the initiatives overlap with those identified in South Africa. For instance, as in South Africa, there has been a steady increase in the labour participation of women in the UK since the 1950s.50 Women now represent 46 per cent of the total labour force in the UK. ${ }^{51}$ Diverse family models are also prevalent in the UK, with an increase in the number of single-parent households, as well as cohabitations and heterosexual partnerships. ${ }^{52}$ The occurrence of such modern family models is also increasing in South Africa. ${ }^{53}$ Other identifiable factors that are common to both jurisdictions are the predisposition of women to be found in part-time or atypical employment; ${ }^{54}$ the need to encourage active participation in caregiving by fathers; 55 and the need to address gender inequalities in the workplace arising from the gendered division of work and care. ${ }^{56}$

This has resulted in the adoption of a statutory maternity leave period of 52 weeks in the UK. ${ }^{57}$ Statutory maternity leave in the UK is made up of "compulsory maternity leave" (the first two weeks following the birth of the child), "ordinary maternity leave" (the first 26 weeks), and "additional maternity leave" (the last 26 weeks). ${ }^{58}$ An employer may not permit an employee to work in the two weeks after childbirth, making up the compulsory maternity leave period. ${ }^{59}$ Employees who have taken maternity leave are entitled to maternity pay in the form of a maternity allowance or statutory maternity pay, provided they meet the applicable eligibility

49 Golynker 2015 Journal of Social Welfare and Family Law 378; Conaghan in Conaghan and Rittich Labour Law, Work and Family 27; Caracciolo di Torella "New Labour, New Dads: The Impact of Family Friendly Legislation on Fathers" 200736 Industrial Law Journal 318; Lewis, Knijn, Martin and Ostner "Patterns of Development in Work/Family Reconciliation Policies for Parents in France, Germany, the Netherlands, and the UK in the 2000s" 2008 15(3) Social Politics: International Studies in Gender, State and Society 261 270; Mitchell "Encouraging Fathers to Care: The Children and Families Act 2014 and Shared Parental Leave" 2015 44(1) Industrial Law Journal 123; James The Legal Regulation of Pregnancy and Parenting in the Labour Market 39.

50 Busby and James Families, Care-Giving and Paid Work: Challenging Labour Law in the 21st Century (2011) 15.

51 The World Bank "Labor Force, Female (\% of Total Labor Force)" The World Bank Databank (2019) http://data.worldbank.org/indicator/SL.TLF.TOTL.FE.ZS (accessed 2019-11-13).

52 James The Legal Regulation of Pregnancy and Parenting in the Labour Market 4; Lewis "Employment and Care: The Policy Problem, Gender Equality and the Issue of Choice" 2006 8(2) Journal of Comparative Policy Analysis 103105.

53 Behari 2018 ILJ 2150.

54 Lewis and Campbell "UK Work/Family Balance Policies and Gender Equality 1997-2005" 2007 14(1) Social Politics: International Studies in Gender, State and Society 49.

55 Caracciolo di Torella 2007 Industrial Law Journal 319.

56 Lewis and Campbell 2007 Social Politics: International Studies in Gender, State and Society 10.

57 S 71(3) of the Employment Rights Act 1996 c. 18 (U.K.) (Employment Rights Act).

58 Emir Selwyn's Law of Employment (2016) 189; James The Legal Regulation of Pregnancy and Parenting in the Labour Market 41.

59 Rickard "Getting Off the Mommy Track: An International Model Law Solution to the Global Maternity Discrimination Crisis" 201447 Vanderbilt Journal of Transitional Law 14651490. 
requirements. 60 As of 1 April 2007, an employee who has given birth is entitled to 39 weeks (or nine months) of statutory maternity pay. ${ }^{61}$ If an employee does not qualify for statutory maternity pay, then she may qualify for 39 weeks of maternity allowance. ${ }^{62}$

Employed fathers, who are responsible for the care of a child, are entitled to one or two consecutive weeks of paternity leave. ${ }^{63}$ The leave may be taken for the purpose of caring for a child or supporting the mother of the child. ${ }^{64}$ The leave may be taken within 56 days after the birth of a child or the placement of an adopted child. ${ }^{65}$ Statutory paternity pay is payable for two weeks at a fixed rate. ${ }^{66}$

In addition to maternity leave and paternity leave, parental leave, or shared parental leave is available to employed mothers or fathers, provided they meet the qualifying requirements attached to the entitlement. ${ }^{67}$ These leave entitlements also extend to partners of the mother of the child, and adoptive parents. ${ }^{68}$

\section{Parental leave}

Parental leave in the UK is regulated by the Maternity and Parental Leave etc. (Terms and Conditions of Employment) Regulations, 1999, which provide that employees are entitled to 18 weeks of parental leave. 69 Parental leave may be claimed for the purpose of caring for a child. ${ }^{70}$ In order to be eligible for parental leave, the employee must have been continuously employed for a period of one year, and must be responsible for the care of the child. ${ }^{71}$ An employee is responsible for the care of a child if he or she has "parental responsibility" over the child as set out in section 3 of the Children Act, $1989 .{ }^{72}$

60 Social Security Contributions and Benefits Act 1992 c. 4 (U.K.) (Social Security Contributions and Benefits Act); Statutory Maternity Pay (General) Regulations 1986 (U.K.) SI 1986/1960 (Statutory Maternity Pay Regulations).

61 S 165 of the Social Security Contributions and Benefits Act; reg 2 of the Statutory Maternity Pay Regulations; the Statutory Maternity Pay, Social Security (Maternity Allowance) and Social Security (Overlapping Benefits) (Amendment) Regulations 2006 (UK) SI 2009/2379.

62 S 35(2) of the Social Security Contributions and Benefits Act states that a maternity allowance shall be payable for the period which, if she were entitled to statutory maternity pay, would be the maternity pay period.

63 S 80 of the Employment Rights Act; reg 5(1) of the Paternity and Adoption Leave Regulations.

64 Reg 4(1) of the Paternity and Adoption Leave Regulations.

65 Reg 5(2) of the Paternity and Adoption Leave Regulations.

66 S 171ZE of the Social Security Contributions and Benefits Act; Emir Selwyn's Law of Employment 202.

67 Employment Rights Act.

68 Ibid.

69 The Maternity and Parental Leave etc. (Terms and Conditions of Employment) Regulations 1999 (UK), SI 1999/3312 (Maternity and Parental Leave Regulations).

70 Reg 13 of the Maternity and Parental Leave Regulations.

71 Emir Selwyn's Law of Employment 192.

72 Reg 2 and 13 of the Maternity and Parental Leave Regulations; s 3 of the Children Act 1989 c. 41 (U.K.) 
In terms of this provision, the parent must have all the rights, duties, powers, responsibilities and authority that by law a parent of a child has in relation to the child and his property. ${ }^{73}$ The mother of the child is automatically considered to have parental responsibility for the child. The father will acquire parental responsibility only if he is married to the child's mother; or, if he is unmarried, he will acquire parental responsibility as the child's father upon the registration of the birth, or by the conclusion of a parental responsibility agreement, or by a court order. ${ }^{74}$ Furthermore, guardians and adoptive parents of the child may also qualify for parental leave. ${ }^{75}$

The right to take parental leave is non-transferrable between parents and endures from the time the child is born until the child reaches the age of 18 years. ${ }^{76}$ The qualifying employee may take up to four weeks of leave in one year. ${ }^{77}$ The leave must be taken in complete blocks. This means that if the employee takes only a few days of the week as parental leave, it will still count as a week of parental leave. ${ }^{78}$ The employee must give at least 21 days' notice of the dates when the leave will be taken. ${ }^{79}$ The regulations make provision for the postponement of leave by the employer where the employer considers that the operation of the business would be unduly disrupted if the employee took leave during the period identified in his notice. However, the leave cannot be postponed for longer than six months. ${ }^{80}$

Parental leave is unpaid. ${ }^{81} \mathrm{It}$ is for this reason that parental leave is not often used by employees. ${ }^{82}$ Most employees cannot afford to take unpaid absences from work. ${ }^{83}$ This is particularly the case for fathers, who are often the primary financial income providers of the family. ${ }^{84}$ Nevertheless, employed fathers are entitled to paid paternity leave.

\section{Shared parental leave}

Shared parental leave and pay was introduced by the Children and Families Act, 201485 with the intention of encouraging shared parental care-giving responsibilities and providing flexibility for the involvement of fathers in family care. ${ }^{86}$ Shared parental leave allows the employee on maternity leave to convert part of her maternity leave to shared parental leave, which may be

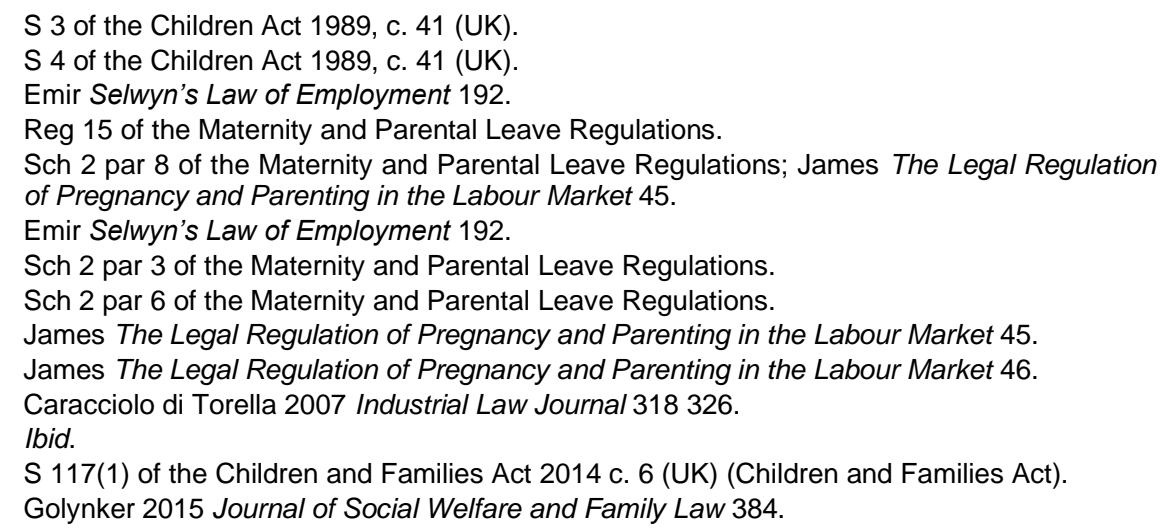


shared with her spouse or partner. ${ }^{87}$ The leave entitlement is applicable to eligible parents of children born on or after 5 April 2015.88 Shared parental leave and pay applies to the eligible mother/adopter of a child, and the child's father/adoptive parent, or the mother's/adopter's partner. ${ }^{89}$ It is described as a "new statutory right" for employees with a partner who is working, or who has recently been working, as an employed earner or as self-employed..$^{90}$ The new statutory right allows eligible employees to share up to 50 weeks of shared parental leave and up to 37 weeks of statutory shared parental pay with the co-parent. ${ }^{91}$

\section{The application of shared parental leave}

Shared parental leave operates by enabling the eligible employee to reduce her maternity leave or adoption leave upon reaching the end of the compulsory leave period. This is known as "the entitlement to curtail statutory rights to leave". ${ }^{92}$ The remainder of the untaken maternity or adoption leave may be taken as shared parental leave.

The leave may be curtailed upon notice to curtail maternity or adoption leave at a specified future date, or by simply returning to work. ${ }^{93}$ The remaining maternity leave or adoption leave is then transferred to the coparent. ${ }^{94}$ Essentially, shared parental leave may encompass a period of 50 weeks, made up of 52 weeks of maternity leave, minus two weeks of compulsory maternity leave. ${ }^{95}$ As such, it works alongside traditional maternity leave to provide working parents with more flexibility and choice when reconciling employment and family demands. ${ }^{96}$

\section{Shared parental leave period claims}

Shared parental leave may be claimed any time between the birth of a child, or the placement of a child for adoption or placement with prospective adopters, and the child's first birthday or the first anniversary of the

87 Children and Families Act; Golynker 2015 Journal of Social Welfare and Family Law 383.

88 S 75E of the Employment Rights Act; reg 2(1) of the Shared Parental Leave (Terms and Conditions of Employment) Regulations 2014 (UK) SI 2014/3050 (the Shared Parental Leave Regulations); reg 3 of the Statutory Shared Parental Pay (General) Regulations 2014 (UK) SI 2014/3051 (Statutory Shared Parental Pay Regulations).

89 Explanatory Memorandum to the Shared Parental Leave Regulations; Statutory Shared Parental Pay Regulations; Maternity and Adoption Leave (Curtailment of Statutory Rights of Leave) Regulations 2014 (UK) SI 2014/3052 (Maternity and Adoption Leave (Curtailment) Regulations).

90 Explanatory Memorandum to the Shared Parental Leave Regulations; Statutory Shared Parental Pay Regulations; Maternity and Adoption Leave (Curtailment) Regulations.

91 Shared Parental Leave Regulations; Statutory Shared Parental Pay Regulations.

92 Maternity and Adoption Leave (Curtailment) Regulations.

93 Maternity and Adoption Leave (Curtailment) Regulations; Explanatory Memorandum to the Shared Parental Leave Regulations; Statutory Shared Parental Pay Regulations.

94 Emir Selwyn's Law of Employment 202.

95 Reg 6 of the Shared Parental Leave Regulations.

96 Golynker 2015 Journal of Social Welfare and Family Law 384; Emir Selwyn's Law of Employment 202. 
placement. ${ }^{97}$ The leave must be taken in complete blocks, although the blocks of leave may be continuous or discontinuous. ${ }^{98}$ Each parent is entitled to three continuous blocks of leave. The leave of each parent may be taken at the same time or separately. ${ }^{99}$

Therefore, employees can take leave in a continuous block or they can return to work intermittently between their periods of leave. ${ }^{100}$ The minimum period of shared parental leave that may be taken is one week. ${ }^{101}$ The structure of a 50-week leave entitlement available to both parents of a child is supportive of shared parental care. ${ }^{102}$ By providing parents with the choice of accessing their leave continuously or in discontinuous blocks, together with the provision that the leave may be taken by the parents at the same time or separately, means that the law does not intend to prescribe caregiving roles to the parents. ${ }^{103}$ The parents are allowed to structure the leave according to their family needs. ${ }^{104}$

\section{Statutory shared parental pay}

Shared parental pay arises from the transfer of untaken statutory maternity pay. ${ }^{105}$ Statutory maternity pay due to a mother may be transferred as statutory shared parental pay. ${ }^{106} \mathrm{~A}$ mother/adopter and a co-parent to whom the shared parental leave is transferred is entitled to statutory shared parental pay for a total of 39 weeks, less the number of weeks that statutory maternity pay is paid to the mother. ${ }^{107}$ Shared parental leave is paid at a weekly rate of $£ 138.18$ a week, or 90 per cent of the normal weekly earnings of the individual claiming statutory shared parental pay, whichever amount is less. ${ }^{108}$ The final 13 weeks of statutory shared parental leave is unpaid. ${ }^{109}$ Statutory shared parental pay is not payable after the child's first birthday or the first anniversary of the placement for adoption. ${ }^{110}$

97 Reg 7(1) of the Shared Parental Leave Regulations.

98 Reg 7(2) and (3) of the Shared Parental Leave Regulations.

99 Reg 16(1) of the Shared Parental Leave Regulations; Mitchell 2015 Industrial Law Journal 127128.

100 Mitchell 2015 Industrial Law Journal 127.

101 Reg 7(4) of the Shared Parental Leave Regulations.

102 Mitchell 2015 Industrial Law Journal 128.

103 Mitchell 2015 Industrial Law Journal 128.

104 Ibid.

105 S 165(3A) of the Social Security Contributions and Benefits Act, as amended by s 120(4) of the Children and Families Act, provides that the duration of the maternity pay period may be reduced in accordance with terms and conditions set out in regulations.

106 Part 12ZC of the Social Security Contributions and Benefits Act; s 119 of the Children and Families Act.

107 Reg 10 of the Statutory Shared Parental Pay Regulations.

108 Reg 40 of the Statutory Shared Parental Pay Regulations.

109 Rickard 2014 Vanderbilt Journal of Transitional Law 1494.

110 Reg 11 of the Shared Parental Leave Regulations; Statutory Shared Parental Pay Regulations. 


\section{Eligibility}

In order to claim shared parental leave and statutory shared parental pay, the mother/adopter must first trigger the leave entitlement by curtailing the statutory maternity leave to which she is entitled; or where she has not curtailed her leave in that way, the mother/adopter has to return to work before the end of her statutory maternity leave. ${ }^{111}$ The mother/adopter and the co-parent must then meet the following requirements to be eligible for shared parental leave and statutory shared parental pay. Both mother/adopter and co-parent must:

- $\quad$ satisfy the continuity-of-employment test, which requires the employee to have been continuously self-employed or employed with an employer for a period of not less than 26 weeks ending with the 15th week before the expected week of birth, or the week in which the adoptive parent has been notified of having been matched for adoption with the child; and to have remained in continuous employment until the week before any period of shared parental leave taken by the employee; 112

- $\quad$ satisfy the employment-and-earnings test, which requires the employee or self-employed earner to have worked for at least 26 weeks in the 66 weeks leading up to the expected week of childbirth, or the week in which the adoptive parent has been notified of having been matched for adoption with the child; and the employee must have earned an average of at least $£ 30$ a week in any 13 weeks; ${ }^{113}$

- at the date of the child's birth, carry out the main responsibility for the care of the child;

- $\quad$ have complied with the condition that notice and evidence of the leave entitlement must be given to their employers; and

- have complied with the condition that a period of leave notice be given to the employer. ${ }^{114}$

Each entitlement to shared parental leave and pay is not affected by the number of children born or expected as a result of the same pregnancy. ${ }^{115}$

Both the mother/adopter and the co-parent must give the employer notice of the entitlement and the intention to take shared parental leave. ${ }^{116}$ Written notice must be given to the employer at least eight weeks before the start of the first period of shared parental leave, and must indicate specified information as set out in the regulations. ${ }^{117}$ The notice must be accompanied by a declaration indicating compliance with the conditions of entitlement for shared parental leave, and consenting to the amount of leave that each

111 Reg 4(2)(d) of the Shared Parental Leave Regulations.

112 Reg 35 of the Shared Parental Leave Regulations.

113 Reg 36 of the Shared Parental Leave Regulations.

114 Shared Parental Leave Regulations; Statutory Shared Parental Pay Regulations.

115 Reg 4(4) and 5(4) of the Shared Parental Leave Regulations; reg 11 of the Statutory Shared Parental Pay Regulations.

116 Reg 8 and 9 of the Shared Parental Leave Regulations; reg 6 and 7 of the Statutory Shared Parental Pay Regulations.

117 Reg 8(1) and 9(1) of the Shared Parental Leave Regulations; reg 6(1) and 7(1) of the Statutory Shared Parental Pay Regulations. 
parent intends to take. ${ }^{118}$ The regulations make provision for the parents to provide further written notice to their employers varying the periods of shared parental leave each parent intends to take. ${ }^{119}$

\section{Employment protection}

The Employment Rights Act, ${ }^{120}$ together with the regulations, provides employment protection to the employee who takes or seeks to take paternity leave, parental leave or shared parental leave. ${ }^{121}$ The Act states that an employee who is absent from work because of parental and shared parental leave is entitled to the benefits, and is bound by the terms and conditions of employment that would have applied had the employee not been absent. ${ }^{122}$ If the employee takes parental or shared parental leave as a period following additional maternity leave or additional adoption leave, she is entitled to return from leave to the job in which she was employed before her absence unless it is not reasonably practicable for her to return to that job. In such an instance, the employer must offer the employee a job that is suitable and appropriate for her to do in the circumstances. ${ }^{123}$ The employee is entitled to terms and conditions of employment that are no less favourable than those that would have applied had she not been absent. ${ }^{124}$ Furthermore, the employee is protected against any detrimental treatment by the employer for the reason that he or she took or sought to take parental or shared parental leave. ${ }^{125}$ The employee is also protected against unfair dismissal on the basis that he or she took or sought to take parental or shared parental leave. ${ }^{126}$

\section{Take-up rates in the UK}

The Fourth Work-Life Balance Employee Survey, 2012 was conducted in 2011 and is the most recent survey reflecting take-up rates of parental leave. According to the survey, 11 per cent of parents with children under the age of six had taken parental leave. ${ }^{127}$ Reports also find a slow take-up rate attached to shared parental leave. ${ }^{128}$ In April 2016, the My Family Care and

118 Reg 8(3) and 9(3) of the Shared Parental Leave Regulations; reg 6(3) and 7(3) of the Statutory Shared Parental Pay Regulations.

119 Reg 11(1) of the Shared Parental Leave Regulations.

120 Employment Rights Act 1996 c. 18 (UK).

121 Reg 18(1) of the Employment Rights Act; Maternity and Parental Leave Regulations; reg 18(1) of the Shared Parental Leave Regulations.

122 Ss $75 \mathrm{I}$ and 77 of the Employment Rights Act.

123 Reg 18(3) of the Maternity and Parental Leave Regulations; reg 18(2) of the Shared Parental Leave Regulations.

124 Reg 18(5) of the Maternity and Parental Leave Regulations; reg 41(3) of the Shared Parental Leave Regulations.

125 Reg 20 of the Maternity and Parental Leave Regulations; reg 42 of the Shared Parental Leave Regulations.

126 S 99 of the Employment Rights Act; reg 20 of the Maternity and Parental Leave Regulations; reg 43 of the Shared Parental Leave Regulations.

127 Ibid.

128 My Family Care and Women's Business Council Shared Parental Leave: Where Are We Now? (2016) https://www.myfamilycare.co.uk/news/blog/shared-parental-leave-our-findings .html (accessed on 2019-12-16). 
Women's Business Council surveyed 200 employers and 1000 employees to determine take-up rates of shared parental leave. ${ }^{129}$ According to the results, only 1 per cent of men have used shared parental leave, while 55 per cent of women stated that they would not want to share their maternity leave. ${ }^{130}$ The main reasons that men had not taken shared parental leave were: financial affordability of the leave, lack of awareness of the right to shared parental leave, and unwillingness of women to share their maternity leave. ${ }^{131}$ However, research indicates that the take-up rates are set to rise, as 63 per cent of male employees with young children indicated they would consider taking up shared parental leave..$^{132}$ The Maternity and Paternity Rights and Women Returners Survey 2009/10 indicated that 49 per cent of fathers had taken statutory paternity leave. ${ }^{133}$ The majority of employees who had taken statutory paternity leave used the full two-week duration of statutory paternity leave.

\section{COMPARATIVE ANALYSIS}

The UK has two models of parental leave, both of which are highly regulated by legislative eligibility requirements but which nevertheless provide more flexibility and support to parents with caregiving responsibilities than the parental leave model of South Africa.

The duration of parental leave in South Africa is at least 10 consecutive days. ${ }^{134}$ By contrast, the UK offers an eligible employee 18 weeks of parental leave, albeit unpaid, with a maximum of 4 weeks per year. Shared parental leave allows the parents to share the applicable maternity leave period between themselves. Thus, the UK offers longer periods of parental leave than South Africa does.

It is assumed that the words "at least" in section $25 \mathrm{~A}(1)$ of the BCEA, as amended, were made to correspond with the wording of the right to maternity leave in section 25 of the BCEA. Section 25 states: "An employee is entitled to at least four months' consecutive maternity leave." In this provision, the words "at least" accounts for instances where the duration of maternity leave is extended by collective agreements or by agreements between the employer and the employee. ${ }^{135}$ Similar conditions would apply

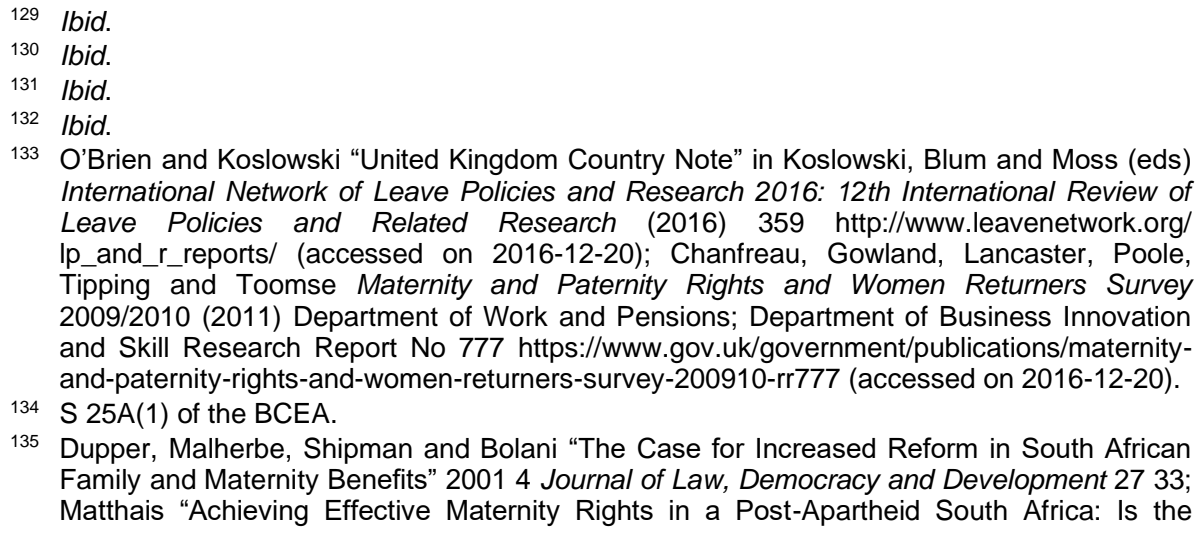

O'Brien and Koslowski "United Kingdom Country Note" in Koslowski, Blum and Moss (eds) International Network of Leave Policies and Research 2016: 12th International Review of Leave Policies and Related Research (2016) 359 http://www.leavenetwork.org/ Ip_and_r_reports/ (accessed on 2016-12-20); Chanfreau, Gowland, Lancaster, Poole, Tipping and Toomse Maternity and Paternity Rights and Women Returners Survey 2009/2010 (2011) Department of Work and Pensions; Department of Business Innovation and Skill Research Report No 777 https://www.gov.uk/government/publications/maternityand-paternity-rights-and-women-returners-survey-200910-rr777 (accessed on 2016-12-20).

$134 \mathrm{~S} 25 \mathrm{~A}(1)$ of the BCEA.

135 Dupper, Malherbe, Shipman and Bolani "The Case for Increased Reform in South African Family and Maternity Benefits" 20014 Journal of Law, Democracy and Development 27 33; Matthais "Achieving Effective Maternity Rights in a Post-Apartheid South Africa: Is the 
to parental leave. Nevertheless, section $26 \mathrm{~A}(4)$ of the UIA, as amended, states that the maximum period for which parental leave benefits may be claimed is 10 consecutive days.

The provision in South Africa for a shorter duration of parental leave (10 days) seems unlikely to interrupt the business of the employer. This is unlike parental leave in the UK, which provides for 18 weeks of parental leave, therefore requiring the further provision that allows the employer to postpone the leave for a period of six months so that it does not disrupt business operations. ${ }^{136}$ Ten days of leave is less likely to impact the employer through the interruption of commercial activities.

The leave in the South African model can only be used upon the birth of a child. ${ }^{137}$ It fails to provide continued caregiving support to parents with young children. By contrast, parental leave in the UK is applicable to parents of children under the age of $18 .{ }^{138}$ Thus, the South African model of parental leave fails to account for the ongoing caregiving responsibilities of working parents with young children. However, the amendments retain the right to family responsibility leave for the purpose of taking care of a sick child. ${ }^{139}$ In terms of this right, a parent with a young child who falls ill is entitled to three days of family responsibility leave per annual leave cycle. ${ }^{140}$ If the parent has used up his or her family responsibility leave, he or she will have to rely on annual leave to take time off from work to attend to the child. In this respect, the parental leave model of South Africa fails to provide long-term support to working parents with young children.

Both parental leave and shared parental leave in the UK have strict eligibility requirements that must be met before the employee can rely on either of the leave entitlements. The South African right to parental leave does not set out detailed eligibility requirements. The failure to define the term "parent" in section 25A(1) of the BCEA, as amended, leads to a lack of clarity as to the applicability of parental leave. The provision operates on the interpretation that the "parent" of the child is referring to either a mother or the father. ${ }^{141}$ It may also lead to the adoption of a broad understanding of "father," which is consistent with African culture, where the role of father can be ascribed to an uncle, stepfather or grandfather. ${ }^{142}$

Parental leave in the UK is applicable to an employee who has parental responsibility for the child in terms of the UK Children's Act, 1989. ${ }^{143}$ Thus, the UK legislation clearly indicates in which instances a mother and a father will qualify for parental leave. Similarly, the right to shared parental leave indicates explicitly the persons eligible for the leave within the legislative

Constitution Adequate?" 1995 28(2) The Comparative and International Journal of Southern Africa 251252.

136 Maternity and Parental Leave Regulations.

137 S 25A(1) of the BCEA.

138 Reg 15 of the Maternity and Parental Leave Regulations.

$139 \mathrm{~S} 27(2)(b)$ of the BCEA.

140 Ibid.

141 Behari 2018 ILJ 2152; Rycroft and Duffy 2019 ILJ 22.

142 Rycroft and Duffy 2019 ILJ 22.

143 Reg 2 and 13 of the Maternity and Parental Leave Regulations; s 3 of the Children Act 1989, c. 41 (UK). 
provision of the right. ${ }^{144}$ It is submitted that the South African right to parental leave would have benefited from a reliance on the definition of "parent" in the Children's Act 38 of 2005. In such an instance, the BCEA would state that the employee would be considered as a "parent" of the child if he or she has "parental rights and responsibilities" over the child as set out in the Children's Act 38 of 2005 . This would provide clear parameters to the application of parental leave.

As in the UK parental leave models, the South African right to parental leave is also available to adoptive parents. ${ }^{145}$ However, its application to mothers remains uncertain for a number of reasons. First, section $25 \mathrm{~A}(2)(\mathrm{a})$ of the LLAA states that an employee may commence parental leave on the day that the child is born or when the adoption order is granted. This suggests that parental leave may only be taken immediately after the birth of the child. If this is the case, then it would exclude the application of parental leave to all biological mothers, as mothers would be on compulsory maternity leave for two weeks after giving birth. This would indicate that the mother who has taken maternity leave will not be entitled to apply for parental leave once her maternity leave period ends.

Secondly, there is little clarity on whether the mother who has taken maternity leave will be entitled to apply for parental leave once her maternity leave period ends. ${ }^{146}$ Rycroft and Duffy argue that parental leave is intended for the parent who is not the primary nurturer of the child. ${ }^{147}$ This argument rests on the assumption that the primary nurturer of the child will be entitled to either maternity leave, adoption leave or commissioning parental leave under the BCEA, and that parental leave is to be taken by the secondary nurturer. ${ }^{148}$ Nevertheless, where the employee is the mother of the child, she will not be able to claim parental benefits in terms of the UIA, as she will not be able to meet the qualifying requirement that the employee be the registered father of the child. ${ }^{149}$

A further shortcoming of the right to parental benefits in South Africa is that a female partner in a same-sex relationship will not be able to rely on parental benefits where her partner is the biological mother of the child and is entitled to maternity leave and benefits, while she, as the other parent, takes parental leave. Here too, the employee will be excluded from parental benefits as she will not be able to meet the qualifying requirement that the employee be registered as the father of the child. ${ }^{150}$ The requirement that the employee must be the registered father of the child thus narrows the scope of parental leave and inevitably excludes categories of women despite its gender-neutral appearance.

Parental leave in the UK has an unbiased structure in that it allows either the mother or the father, or both partners in a same-sex partnership

144 Explanatory Memorandum to the Shared Parental Leave Regulations; the Statutory Shared Parental Pay Regulations; Maternity and Adoption Leave (Curtailment) Regulations.

$145 \mathrm{~S} 25 \mathrm{~A}(2)(b)$ of the BCEA.

146 Behari 2018 ILJ 2153; Rycroft and Duffy 2019 ILJ 19.

147 Rycroft and Duffy 2019 ILJ 17.

148 Behari 2018 ILJ 2153; Rycroft and Duffy 2019 ILJ 20.

$149 \mathrm{~S} 26 \mathrm{~A}(1)$ of the BCEA.

150 Behari 2018 ILJ 2158. 
(whether male or female), to apply for a non-transferable entitlement of leave. Each parent is entitled to their own individual right to parental leave, which encourages each parent to use the right, irrespective of whether they are the mother or the father. Non-transferable parental leave allows both the mother and the father of the child to exercise a separate and individual entitlement to parental leave. ${ }^{151}$ This encourages fathers to take parental leave and assists in the sharing of parental responsibilities between parents. The extension of the leave provision as an individual entitlement to fathers also assists in the promotion of an expanded caregiving role for fathers. ${ }^{152}$ Shared parental leave in the UK appears to be aimed at assisting the mother with postnatal caregiving during her maternity period. It operates on the basis that the mother is offered a long maternity leave period, during which time she may want to return to work, in which case she can rely on the father/partner to take time off to assist with the care of the baby. ${ }^{153}$ Both parents have the opportunity to care for the newborn or newly adopted baby.

In this respect, the South African model of parental leave fails to provide support for working mothers who have caregiving responsibilities for a newborn baby after the maternity leave period, as the mother cannot take parental leave once she exhausts her maternity leave. Owing to the limited applicability of parental leave to females, it appears that the right was better suited to be structured as a form of paternity leave rather than a genderneutral parental leave entitlement. The true purpose of the South African model of parental leave is to offer fathers time off from work to care for a newborn baby, and to share in the caregiving with the mother who is on maternity leave. However, it must be noted that reliance on the UIA to provide parental leave benefits may affect the take-up rates of parental leave by fathers.

Family responsibility leave was previously paid by the employer at the full rate of the employee's remuneration. ${ }^{154}$ By contrast, parental benefits are paid at a maximum rate of 66 per cent of the employee's remuneration. Thus, the employee who takes parental leave and relies on parental benefits will not be receiving full remuneration over the parental leave period. Parental leave in the UK is unpaid. Thus, while it is commendable that there are benefits attached to parental leave in South Africa, the discouraging level of benefits provides little incentive for fathers to take parental leave and may altogether deter a father who is the primary income provider of a household from taking parental leave. ${ }^{155}$

Furthermore, a significant exclusion from the introduction to parental leave is the provision of employment protection under the Labour Relations Act $(\text { LRA })^{156}$ and the Employment Equity Act (EEA). ${ }^{157}$ Currently, the LRA

151 Huysamen in Malherbe and Sloth-Nielsen Labour Law into the Future: Essays in Honour of D'Arcy du Toit 73.

152 Morrell and Richter "Introduction" in Richter and Morrell (eds) Baba: Men and Fatherhood in South Africa (2006) 3.

153 Golynker 2015 Journal of Social Welfare and Family Law 378383.

$154 \mathrm{~S} 27(3)(a)$ and $(b)$ of the BCEA.

155 Behari 2018 ILJ 2160.

15666 of 1995.

15755 of 1998. 
provides protection against the dismissal of pregnant employees and employees with family responsibilities. ${ }^{158}$ The EEA also provides protection from discrimination for pregnant employees and employees with family responsibilities. ${ }^{159}$ As set out above, UK legislation provides employment protection to employees who take parental leave and shared parental leave. It is submitted that the LRA and EEA should be amended in like vein to ensure that an employee who has taken parental leave be entitled to return to the job in which he or she was employed. The employee must also be protected against unfair dismissal and unfair discrimination on the basis that he or she took or sought to take parental leave.

This article recommends that section $187(1)$ (c) of the LRA should be amended to ensure that the refusal to allow an employee to resume work after he has taken parental leave amounts to a dismissal. Section 187(1)(f) of the LRA should be amended to state that a dismissal is automatically unfair if an employer unfairly discriminates against an employee on grounds that include that the employee took or sought to take parental leave. ${ }^{160}$ Furthermore, section 6(1) of the EEA should be amended to provide that no person may unfairly discriminate, directly or indirectly, against any employee in any employment policy or practice, on grounds that include that the employee took or sought to take parental leave.

In initiating these developments, South Africa may follow the lead of the UK in committing itself to the adoption of legislated family-friendly entitlements that will provide employees with the employment protection needed to support their caregiving responsibilities. ${ }^{161}$ Against the background of a different socio-economic and political context, South Africa cannot be expected to have taken strides as progressive within the area of work-care reconciliation as those taken by the UK. ${ }^{162}$ However, there is a need for South African labour law to commit itself to the further development of leave entitlements that will provide employees with more effective rights and protection to take time off from work to attend to their caregiving responsibilities.

\section{$6 \quad$ CONCLUSION}

The comparative analysis of the South African model of parental leave against parental leave entitlements in the UK has indicated that the legislative framework of South African parental leave offers limited rights and

$S 186(1)(c)$ and $s$ 187(1)(e) of the LRA.

596 of the EEA.

160 S 187 provides: "(1) A dismissal is automatically unfair if the employer, in dismissing the employee, acts contrary to 5 or, if the reason for the dismissal is- ..

(f) that the employer unfairly discriminated against an employee, directly or indirectly, on any arbitrary ground, including, but not limited to race, gender, sex, ethnic or social origin, colour, sexual orientation, age, disability, religion, conscience, belief, political opinion, culture, language, marital status or family responsibility."

161 Field et al 2012 SALR 39; Lewis and Campbell 2007 Social Politics: International Studies in Gender, State and Society 21; Dancaster and Baird 2008 ILJ 41.

162 Bonthuys in Bonthuys and Albertyn Gender, Law and Justice 251; Dancaster and Baird 2008 ILJ 23; Smit 2011 Journal of Comparative Family Studies 20; Albertyn "Substantive Equality and Transformation in South Africa" 200723 SAJHR 253255261. 
protections to employees with care responsibilities. Parental leave implies that the leave is applicable to both mothers and fathers. However, the South African model of parental leave is one-sided as it applies more directly to fathers than to both parents equally. This leaves one to question why it was modelled as parental leave at all, rather than as a right to paternity leave. It is also crucial that further legislative amendments are made to provide employment protection and non-discrimination measures to employees who rely on parental leave in South Africa. The commitment of the South African government is needed to develop the current model of parental leave into a legal mechanism that can support both parents and achieve gender equality in the workplace and the home. 